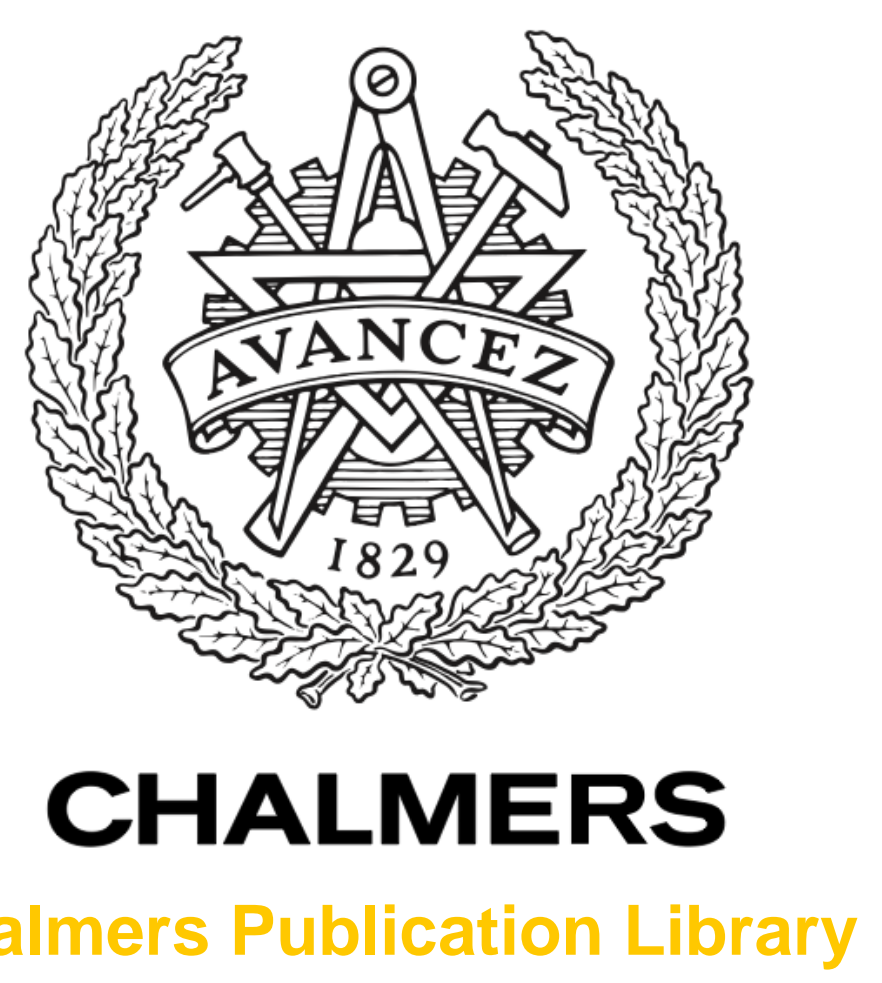

Challmers Publication Library

FATE OF PHOSPHORUS DURING CO-COMBUSTION OF RAPESEED CAKE

This document has been downloaded from Chalmers Publication Library (CPL). It is the author's version of a work that was accepted for publication in:

Proceedings of the 20th International Conference on Fluidized Bed Combustion

Citation for the published paper:

Piotrowska, P. ; Zevenhoven, M. ; Hupa, M. et al. (2009) "FATE OF PHOSPHORUS

DURING CO-COMBUSTION OF RAPESEED CAKE". Proceedings of the 20th

International Conference on Fluidized Bed Combustion, vol. 2 pp. 979-986.

Downloaded from: http://publications.lib.chalmers.se/publication/237920

Notice: Changes introduced as a result of publishing processes such as copy-editing and formatting may not be reflected in this document. For a definitive version of this work, please refer to the published source. Please note that access to the published version might require a subscription. 


\section{Progecalings of}

\section{the $20 \mathrm{~h}$ International conierence on}

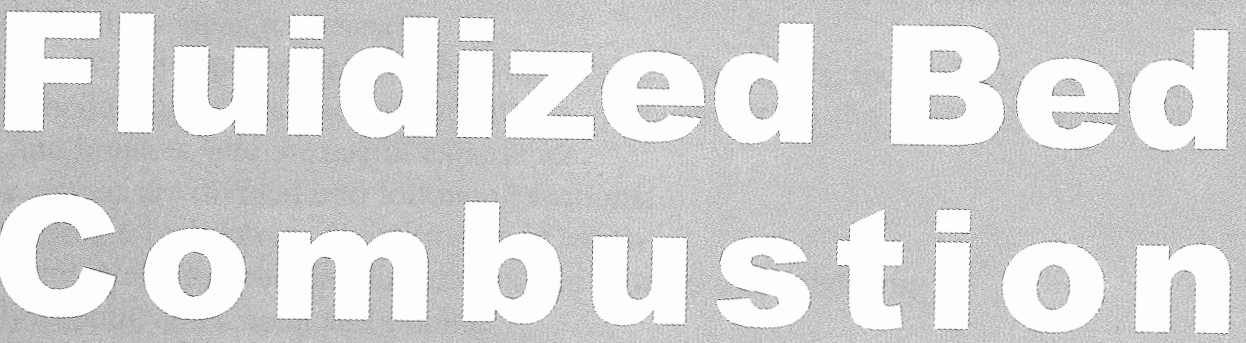

\section{(II)}

Edited by

Guangxi Yue

Hai Zhang

Changsui Zhao

Zhongyang Luo 


\title{
FATE OF PHOSPHORUS DURING CO-COMBUSTION OF RAPESEED CAKE WITH WOOD
}

\author{
Patrycja Piotrowska $^{* 1}$, Maria Zevenhoven ${ }^{1}$, Mikko Hupa ${ }^{1}$, \\ Kent Davidsson ${ }^{2}$, Lars-Erik Åmand², \\ Edgardo Coda Zabetta ${ }^{3}$, Vesna Barišicic ${ }^{3}$ \\ ${ }^{1}$ Process Chemistry Centre, Abo Akademi University, Turku, Finland \\ ${ }^{2}$ Department of Energy and Environment, Division of Energy Technology, Chalmers University of \\ Technology, Gothenburg, Sweden \\ ${ }^{3}$ R\&D Department, Foster Wheeler Energia Oy, Varkaus, Finland \\ * corresponding author: ppiotrow@abo.fi
}

\begin{abstract}
Recent studies show that deposit formation and agglomeration in fluidized bed boilers may be aggravated by a high phosphorus content besides alkali metals, chlorine and sulphur in a fuel. This paper presents the fate of phosphorus during co-combustion of wood chips and wood pellets with rapeseed cake pellets, a high phosphorus fuel in a $12 \mathrm{MW} \mathrm{CFB}$ boiler. 12 hour tests with $12 \%$ and $18 \%$ (energy basis) of rapeseed cake with wood were performed with and without limestone addition. All fuels were characterised by means of standard fuel analyses combined with chemical fractionation. Retrieved ash samples were analysed using wet chemical analysis complemented with SEM/EDXA. Gaseous alkali metal chlorides as well as $\mathrm{HCl}$ and $\mathrm{SO}_{2}$ were measured upstream of the convective pass at a flue gas temperature of $800^{\circ} \mathrm{C}$ where also the deposit samples were collected with a deposit probe. The composition of deposits was studied with SEM/EDXA. Analyses of bed material particle cross-sections showed phosphorus compounds present within a K-silicates matrix between the agglomerated sand particles, indicating direct attack of gaseous potassium compounds on the bed surface followed by adhesion of rich in phosphorus ash particles. Build-up of the deposits took place mainly on the windward side of the probe; where up to $9 \mathrm{wt}-\%$ of phosphorus was present. SEM/EDXA shows that rapeseed cake addition caused an increase of $\mathrm{K}, \mathrm{Na}$ besides $\mathrm{P}$ indicating presence of low melting phosphate salts in the deposits. During limestone addition in the deposit samples the increase of $\mathrm{Cl}$ could be noticed however no significant change in $\mathrm{P}$ content was observed. This paper shows that agglomeration and fouling when co-firing rapeseed cake may be linked to its high content of organically bonded phosphorus - phytic acid salts; together with high content of water soluble fraction of alkali metals chlorides and sulphates in the fuel mixture.
\end{abstract}

Keywords: rapeseed cake, co-combustion, phosphorus, agglomeration, fouling

\section{INTRODUCTION}

In order to save fossil fuels and prevent global warming, biomass, the main one among renewable sources of energy, have been given increased attention. Challenges connected with biomass combustion in fluidized bed boilers, are caused by ash chemistry which may induce agglomeration, fouling and corrosion. It is commonly known that alkali metals, chlorine and sulphur are the main factors lowering the first melting temperature of ash (Hupa M., 2008; Jenkins B.M. et al., 1998). However, recent studies showed that these problems may be aggravated by a high phosphorus content in the fuel (Barišic V. et al., 2008; Coda Zabetta E. et al., 2008; Lindström E. et al., 2007; Nevalainen H. et al., 2008). An interesting example of a fuel rich in phosphorus, alkali metals and chlorine is Rapeseed Cake, a residue from the production of Rapeseed Methyl Ester (RME). Interactions of phosphorus with other ash forming elements during combustion are not fully understood and are subject of this paper.

The work is a continuation of a study on the role of limestone in preventing agglomeration and slagging during CFB combustion of high-phosphorus fuels (Barišić V. et al., 2008). Here the investigation covers both agglomeration and deposit formation during co-combustion of a mixture of wood chips and wood pellets with rapeseed cake pellets. Results are supplemented with gaseous chlorides, sulfates, and alkali metal chlorides present in the beginning of the convective pass. 


\section{EXPERIMENTAL SET-UP}

\section{Boiler}

The 12 MWth CFB boiler located at Chalmers University of Technology, shown in figure 1, was used for the tests. The boiler is large enough to be representative for a semi-industrial CFB boiler and is described in detail elsewhere (Amand L.-E., 2004)

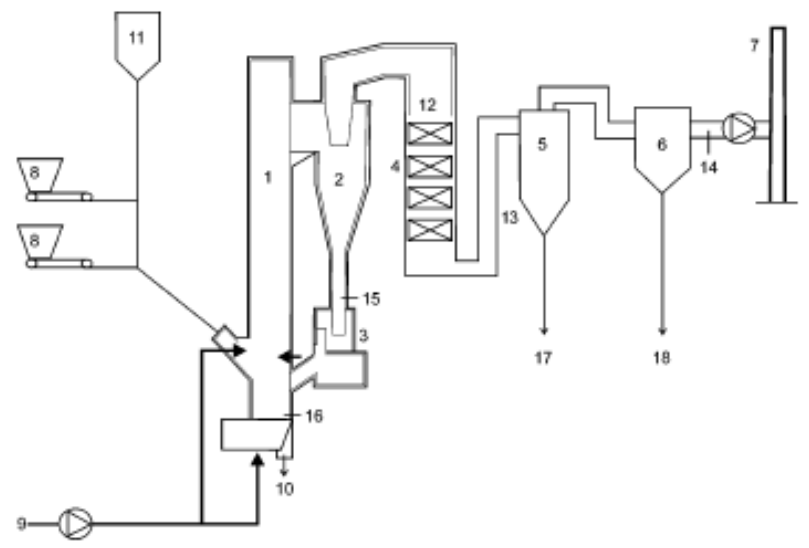

Figure 1 Schematic of the boiler. 1: furnace, 2: primary cyclone, 3: particle seal, 4: convection pass, 5: secondary cyclone, 6: bag-house filter, 7: stack, 8: fuel bunkers, 9: air, 10: bottom material removal, 11: bed sand, 12: measurement position before convection pass, 13: measurement position after convection pass, 14: measurement position after bag-house filter, 15: cyclone leg material sampling spot, 16: bed material sampling spot, 17: secondary cyclone ash sampling, 18: bag-house filter ash sampling.

\section{Combustion experiments}

The experimental plan consisted of $4 \mathrm{~h}$ preliminary tests and $12 \mathrm{~h}$ tests listed in Table 1. The varied parameters were the rapeseed cake (RC) ratio and the addition of limestone $\left(\mathrm{CaCO}_{3}\right)$ to the bed consisting of silica sand. During the tests wood chips (WC) and wood pellets (WP) were used as a base fuel. The highest share of RC was co-combusted during a $4 \mathrm{~h}$ test here named as WNL45_preliminary. This test was preceded with two other $4 \mathrm{~h}$ preliminary tests during which 12 and $21 \%$ (energy basis) of RC was co-fired respectively. During tests WNL12 and WL18 a $\mathrm{RC}$ ratio of 12 and 18\% (energy basis) was used, respectively. In the latter test limestone was added. Both tests lasted approximately $12 \mathrm{~h}$ and were preceded with the reference tests, reference_WNL and reference_WL, when no RC was co-combusted however limestone was used in the latter one. The limestone was taken from Ignaberga in south Sweden. The operational conditions were chosen to represent a typical case of an industrial CFB boiler with a bottom bed temperature of $850^{\circ} \mathrm{C}$ and an excess air ratio of 1.2. The flue gas temperature was maintained at the level of $800^{\circ} \mathrm{C}$ before the convective pass and around $150^{\circ} \mathrm{C}$ in the secondary cyclone and bag house filter in all tests. The load was kept at about $6 \mathrm{MW}$ in all tests corresponding to a fluidizing velocity of about $5 \mathrm{~m} / \mathrm{s}$ in top of the furnace. $12 \mathrm{MW}$ is an overload used for special research activities. Samples from all outgoing solid material streams - namely

Table 1 Rapeseed cake and wood co-combustion tests

\begin{tabular}{|c|c|c|c|c|c|c|c|c|c|}
\hline \multirow[t]{2}{*}{ test name } & \multirow{2}{*}{ 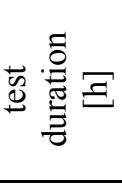 } & \multirow{2}{*}{ 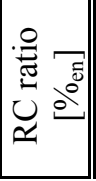 } & \multicolumn{2}{|c|}{$\begin{array}{l}\text { Fuel load } \\
{[\mathrm{kg} \mathrm{ds} / \mathrm{h}]}\end{array}$} & \multicolumn{2}{|c|}{$\begin{array}{c}\text { Ash with fuel }{ }^{1} \\
{[\mathrm{~kg} \text { ash } / \mathrm{h}]}\end{array}$} & \multirow{2}{*}{$\begin{array}{c}\text { Lime } \\
\text { addition } \\
{[\mathrm{kg} / \mathrm{h}]}\end{array}$} & \multirow{2}{*}{$\begin{array}{c}\text { Bed } \\
\text { regen. } \\
{[\mathrm{kg}} \\
\text { sand/h] }\end{array}$} & \multirow{2}{*}{ 苂 } \\
\hline & & & $\mathrm{RC}$ & $\mathrm{WP}+\mathrm{WC}$ & $\mathrm{RC}$ & $\mathrm{WP}+\mathrm{WC}$ & & & \\
\hline WNL12_preliminary & 4 & 12 & 136 & 1175 & 9,4 & 5,1 & 0,0 & 0,0 & 47,2 \\
\hline WNL21_preliminary & 4 & 21 & 229 & 1048 & 15,9 & 4,5 & 0,0 & 0,0 & 37,2 \\
\hline WNL45_preliminary & 4 & 45 & 524 & 771 & 36,3 & 3,3 & 0,0 & 4,4 & 37,5 \\
\hline Reference_WNL & 16 & 0 & 0 & 1309 & 0,0 & 6,4 & 0,0 & 0,0 & 160,1 \\
\hline WNL12 & 13 & 12 & 135 & 1190 & 9,6 & 4,9 & 0,0 & 0,0 & 66,7 \\
\hline Reference_WL & 14 & 0 & 0 & 1328 & 0,0 & 7,0 & 54,5 & 0,0 & 52,9 \\
\hline WL18 & 12 & 18 & 196 & 1101 & 14,0 & 7,6 & 54,9 & 0,6 & 38,1 \\
\hline
\end{tabular}

$\mathrm{RC}$ - rapeseed cake; WP - wood pellets; WC- wood chips; \% $\%_{\mathrm{en}}$ - percentage on energy basis;

${ }^{1}$ - ash content in the fuel measured at ChUT; ${ }^{2}-\left(\right.$ ash $_{\text {out }} /$ ash $\left._{\text {in }}\right) * 100 \%$ 
bed material, secondary cyclone and bag filter, were collected at the end of each test. Deposit samples were collected on steel rings which were fitted on an air-cooling probe situated in the middle of the fluegas stream before the convective pass. The surface temperature of the steel rings was set to $500^{\circ} \mathrm{C}$ during all three preliminary tests and $480^{\circ} \mathrm{C}$ in case of other $12 \mathrm{~h}$ tests to simulate a superheater tube.

\section{Analyses of gases}

In the convective pass gaseous $\mathrm{HCl}$ and $\mathrm{SO}_{2}$ were measured with Fourier Transform Infrared (FT-IR) spectroscopy. In addition gaseous alkali chlorides were continuously measured at this position using the In-situ Alkali Chlorides Monitor (IACM) developed by Vattenfall. The instrument uses a sampling time of 5-10 seconds. The detection limit at a 5 meter measuring length (width of the flue gas channel) is $1 \mathrm{ppm}$ for $\mathrm{KCl}$ and $\mathrm{NaCl}$ (Kassman H. et al., 2006). $\mathrm{HCl}$ emissions were measured by means of FT-IR and $\mathrm{SO}_{2}$ with non dispersive ultra-violet (NDUV) analyzer; the results were used for the mass balances calculation over the boiler.

\section{Analyses of fuels and ash samples}

Fuel samples (WP, WC and RC) were analyzed using standard fuel analysis and chemical fractionation. Chemical fractionation is a method based on selective consecutive leaching by water $\left(\mathrm{H}_{2} \mathrm{O}\right), 1 \mathrm{M}$ ammonium acetate $\left(\mathrm{NH}_{4} \mathrm{Ac}\right.$ ) and $1 \mathrm{M}$ hydrochloric acid $(\mathrm{HCl})$ (Baxter L.L., 1994; Benson S.A., 1985; Skrifvars B.-J. et al., 1998; Zevenhoven M. 2001, Zevenhoven M. et al., 2001, 2004). The increasingly aggressive solvents leach samples into a series of four fractions (including the unleached residue). The untreated samples, the liquid fractions and the remaining solids were analyzed by an external laboratory according to Swedish standards. Ash samples from all outgoing solid material streams were collected and analyzed quantitatively according to ASTM D3683 and ASTM D3682 by the same external laboratory. Additionally semi quantitative analyses of bottom ash and deposit samples (from the windward $\left(0^{\circ}\right)$ side of the deposit ring) were performed by means of SEM/EDX. Hereto, ash samples were mounted on carbon tape and covered with a thin carbon layer. Also the bed material particle cross-sections were studied by

Table 2 Properties of fuels.

\begin{tabular}{|c|c|c|c|c|}
\hline Fuel & & RC & WP & $\mathbf{W C}$ \\
\hline $\mathrm{Ash}^{1}$ & {$[\% \mathrm{db}]$} & 7,5 & 0,4 & $\overline{0,6}$ \\
\hline HHV & {$[\mathrm{MJ} / \mathrm{kg} \mathrm{db}]$} & 22,157 & 20,193 & 19,980 \\
\hline LHV & {$[\mathrm{MJ} / \mathrm{kg} \mathrm{db}]$} & 20,672 & 18,873 & 18,665 \\
\hline $\mathrm{C}$ & {$[\% \mathrm{db}]$} & 49,900 & 50,600 & 49,900 \\
\hline $\mathrm{H}$ & {$[\% \mathrm{db}]$} & 6,900 & 6,100 & 6,000 \\
\hline $\mathrm{N}$ & {$[\% \mathrm{db}]$} & 5,100 & 0,100 & 0,200 \\
\hline $\mathrm{O}$ (calculated) & {$[\% \mathrm{db}]$} & 29,62 & 42,800 & 43,300 \\
\hline $\mathrm{S}$ & {$[\% \mathrm{db}]$} & 0,720 & 0,006 & 0,007 \\
\hline $\mathrm{Cl}$ & {$[\% \mathrm{db}]$} & 0,26 & na & na \\
\hline $\mathrm{Si}$ & {$[\mathrm{mg} / \mathrm{kg} \mathrm{db}]$} & 261,0 & 165,0 & 346,0 \\
\hline $\mathrm{Al}$ & {$[\mathrm{mg} / \mathrm{kg} \mathrm{db}]$} & 43,4 & 36,5 & 207,0 \\
\hline $\mathrm{Fe}$ & {$[\mathrm{mg} / \mathrm{kg} \mathrm{db}]$} & 152,0 & 43,9 & 204,0 \\
\hline $\mathrm{Ti}$ & {$[\mathrm{mg} / \mathrm{kg} \mathrm{db}]$} & 3,6 & 1,8 & 8,4 \\
\hline $\mathrm{Mn}$ & {$[\mathrm{mg} / \mathrm{kg} \mathrm{db}]$} & 59,7 & 112,0 & 166,0 \\
\hline $\mathrm{Ca}$ & {$[\mathrm{mg} / \mathrm{kg} \mathrm{db}]$} & 7040,0 & 783,0 & 1100,0 \\
\hline $\mathrm{Mg}$ & {$[\mathrm{mg} / \mathrm{kg} \mathrm{db}]$} & 4500,0 & 160,0 & 224,0 \\
\hline $\mathrm{P}$ & {$[\mathrm{mg} / \mathrm{kg} \mathrm{db}]$} & 11500,0 & 55,9 & 120,0 \\
\hline $\mathrm{Na}$ & {$[\mathrm{mg} / \mathrm{kg} \mathrm{db}]$} & 4660,0 & 28,9 & 49,7 \\
\hline $\mathrm{K}$ & {$[\mathrm{mg} / \mathrm{kg} \mathrm{db}]$} & 12300,0 & 432,0 & 594,0 \\
\hline
\end{tabular}

'- ashed at $550^{\circ} \mathrm{C} ;{ }^{2}$ - calculated; RC-rapeseed cake, WP- wood pellets, $\mathrm{WC}$ - wood chips; ar - as received, $\mathrm{db}$ - on dry basis; na - not available (below detection limit of $500 \mathrm{ppm}$ ) means of SEM/EDX spot analyses. Hereto investigated samples of bed material particles were embedded in epoxy and polished with ethanol to obtain crosssections and smooth surface that was consecutively covered with carbon for SEM/EDXA.

\section{RESULTS AND DISCUSSION}

\section{Fuel analyses}

Standard fuel analysis, shown in Table 2, indicates clearly the main ash forming matter constituents of rapeseed cake (RC) pellets are potassium and phosphorous, an additional feature is the high content of chlorine. High ash content of RC results in up to 11 times higher $\mathrm{RC}$ ash inflow compared to WP and WC ash inflow during test WNL45-preliminary (Table 1).

Results from the chemical fractionation are presented in Figure 2. This figure shows the elemental composition of the fuel divided into four obtained fractions, facilitating the comparison between the chemical compositions of the co-combusted fuels. Leaching with water releases simple soluble salts, usually volatile alkali compounds, with ammonium acetate the ion exchangeable part of the fuel ash forming matter is released; in the final step the acid soluble inorganic salts are leached while in the rest 


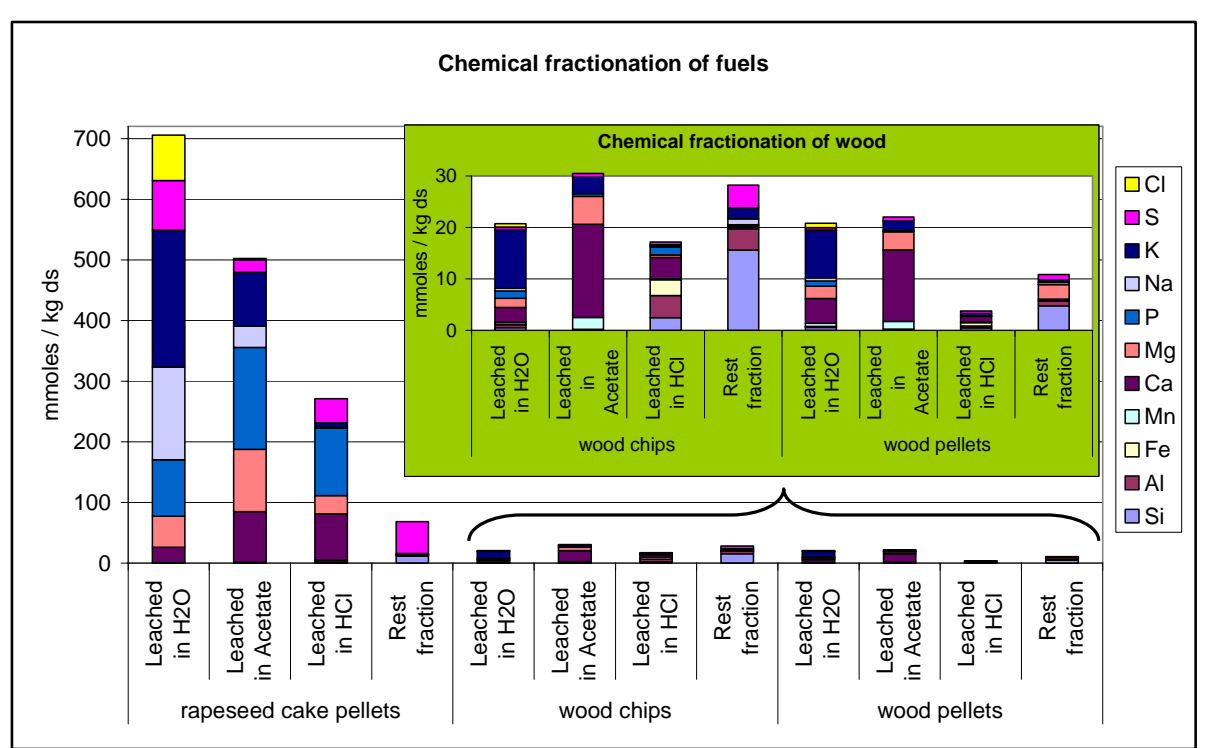

Figure 2 Chemical fractionation results of co-combusted fuels.

(insoluble) fraction mainly silicates are present but also sulphur and chlorine when covalently bonded into the organic structure of the fuel. The chemical fractionation results show that the difference between woody biomass and rapeseed cake is not only the ash content. Woody biomass ash forming matter consists mainly of potassium leached in water and calcium leached by ammonium acetate indicating its association with carboxylic groups of hemicelluloses and calcium oxalate (Werkelin J., 2008; Zevenhoven M., 2001). Only a small amount of phosphorus is found present in the fraction leached by water and hydrochloric acid.

In rapeseed cake high shares of phosphorus are present. This phosphorus is leached in all three procedure steps, indicating different associations. A large part of the rapeseed cake ash forming matter is leached by water indicating simple salts like alkali chlorides, sulphates and phosphates (Werkelin J., 2008; Zevenhoven M., 2001). As shown in previous studies (Pontoppidan K. et al., 2007) around 70\% of total

Table 3 Elemental distribution over outgoing ash fractions - inflow of the element is defined to be $100 \%$

\begin{tabular}{|lc||c|c|c|c|c|}
\cline { 3 - 7 } \multicolumn{1}{c|}{} & \multicolumn{1}{c||}{$\begin{array}{c}\text { Test } \\
\text { name }\end{array}$} & \multicolumn{5}{c|}{ Ash fractions [\%] } \\
\cline { 3 - 7 } \multicolumn{1}{c}{ P } & BA & SC & BF & E & $\Delta$ \\
\hline & WNL12 & - & 21 & 4 & - & 75 \\
\hline \multirow{2}{*}{ K+Na } & WNL12 & - & 23 & 4 & - & 72 \\
\cline { 2 - 7 } & WL18 & 2 & 22 & 12 & - & 64 \\
\hline \multirow{2}{*}{ Mg } & WNL12 & - & 30 & 13 & - & 57 \\
\cline { 2 - 7 } & WL18 & 2 & 26 & 8 & - & 64 \\
\hline \multirow{2}{*}{ W } & WNL12 & - & 9 & 12 & 40 & 40 \\
\cline { 2 - 7 } & WL18 & 2 & 5 & 7 & 1 & 85 \\
\hline \multirow{2}{*}{ Cl } & WNL12 & - & 4 & 17 & 60 & 18 \\
\cline { 2 - 7 } & WL18 & - & 7 & 28 & 5 & 60 \\
\hline
\end{tabular}

BA - bottom ash; SC - secondary cyclone; BF - bag filter; E- emissions;

$\Delta=\left(100 \%-\frac{O u t_{i}}{I n_{i}} \%\right)=$ accumulation + error phosphorus present in rapeseed cake can be associated with phytic acid (myo-inositol hexaphosphate) and its degradation products (mainly inositol pentaphosphate). These phosphorus compounds are probably found in the ammonium acetate and hydrochloric acid fractions. The solubility depends strongly on the type of complexes the phytic acid is forming with cations and proteins (Cheryan M., 1980, Shahidi F., 1990). In the hydrochloric acid fraction mainly calcium, magnesium, but also iron, zinc and manganese were found next to phosphorus.

\section{Mass balance and distribution of ash in the CFB boiler}

The ash balance has been calculated for each test and results are presented in Table 1 . For the calculation all the incoming and outgoing inert flows were used. Ash forming matter entering the boiler with the fuels but also silica entering as substitute for removed bed material and ash produced by limestone addition were considered to constitute the incoming streams. In order to determine the limestone ash flow, the assumption that it fully converts to $\mathrm{CaO}$ to form $\mathrm{CaSO}_{4}$ was made. The closure of the ash balances is shown in Table 1 as the ratio between the total ash outgoing flows to the total ash incoming flows in the percentage form. The closure for $\mathrm{RC}$ co-combustion tests was poor indicating ash accumulation in the system. This was proven after the 4 hour tests that resulted in heavy build up of agglomerates in the particle seal of the boiler. A total shut down of the boiler happened, and the restart was not possible until the particle seal and tube from the cyclone was cleaned 
from large agglomerates. The boiler was started with fresh bed material after which reference test, reference_WNL, was performed. The mass balance closure for reference_WNL of $160 \%$ suggests that ash still present elsewhere in the boiler was removed during the reference case.

Elemental flows were calculated using the quantitative analyses of the incoming and outgoing inert streams. The inflow of the particular element was defined as $100 \%$, and thus the elemental distribution over outgoing streams could be calculated. Results are shown in Table 3. During test WNL12, a forced agglomeration test was performed by shutting off bed regeneration and bottom ash removal (indicated with a "_" in Table 3). The concentration of chlorine in bottom ash samples could not be analyzed due to method detection limit (500 ppm). $\mathrm{Na}$ and $\mathrm{K}$ show a similar behaviour in the boiler and are considered here as a combined fraction of alkali metals. The values presented in Table 3 give an indication of the pathway that ash forming matter is taking through the boiler. It can be seen that high phosphorus and alkali metals accumulation in the boiler and/or convective pass took place. The rest was found in the secondary cyclone ash. In contrast, sulfur and chlorine form small particles that were captured in the bag filter or were emitted in the form of sulfur dioxide or hydrogen chloride. During test with lime addition (WL18), next to obvious sulfur and chlorine retention, a small increase of $\mathrm{K}+\mathrm{Na}$ in the bag filter fraction occurred, most probably caused by increased formation of alkali metal chlorides as shown in Table 4.

\section{The role of $P$ in agglomeration}

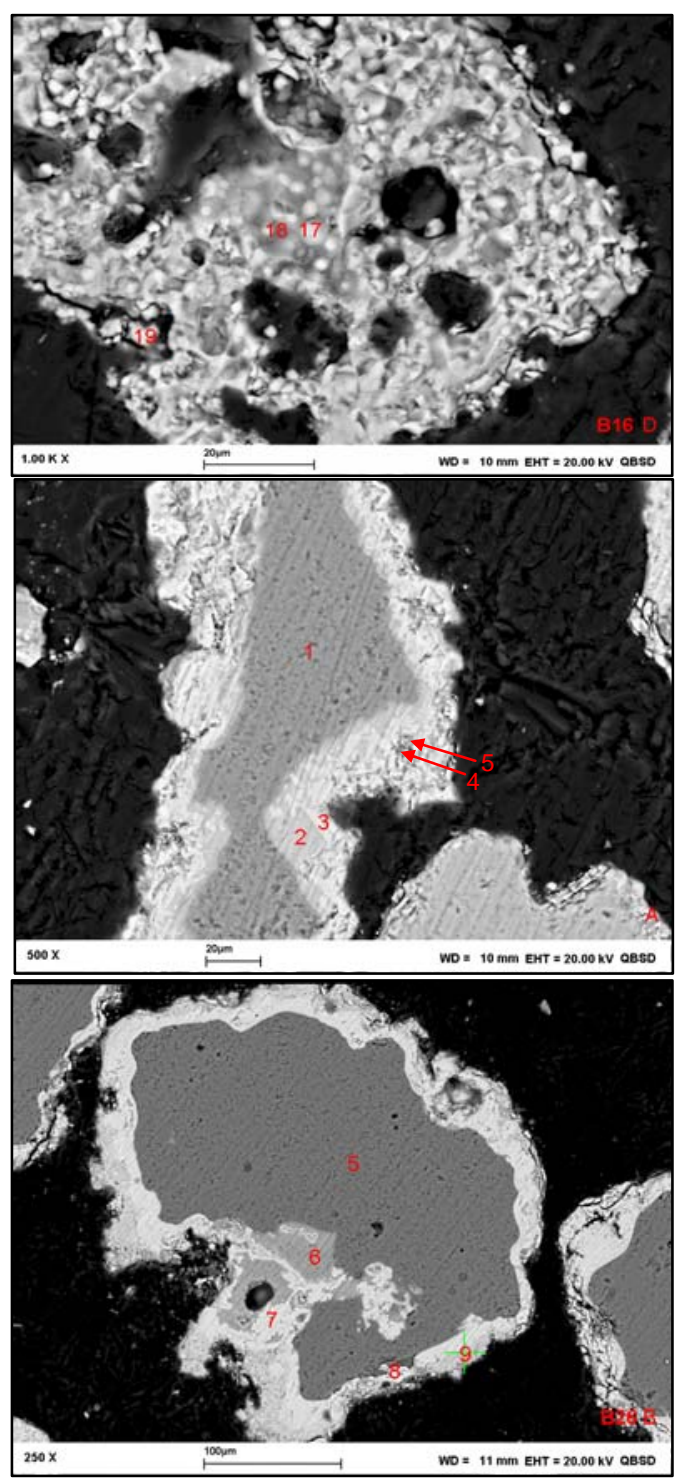

a)

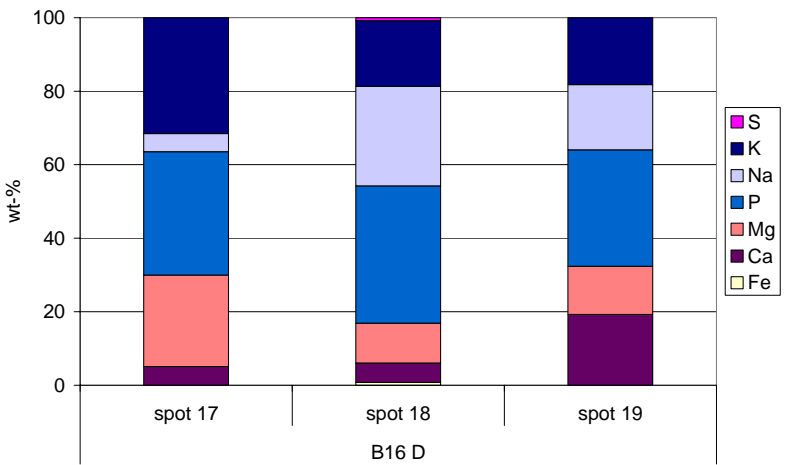

b)

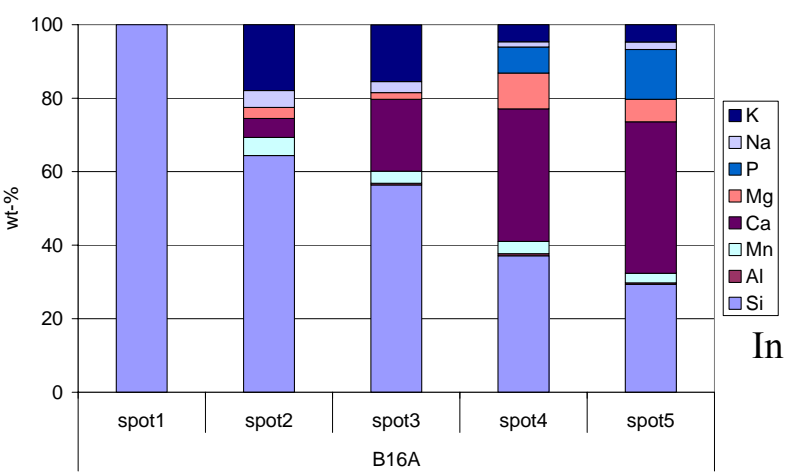

c)

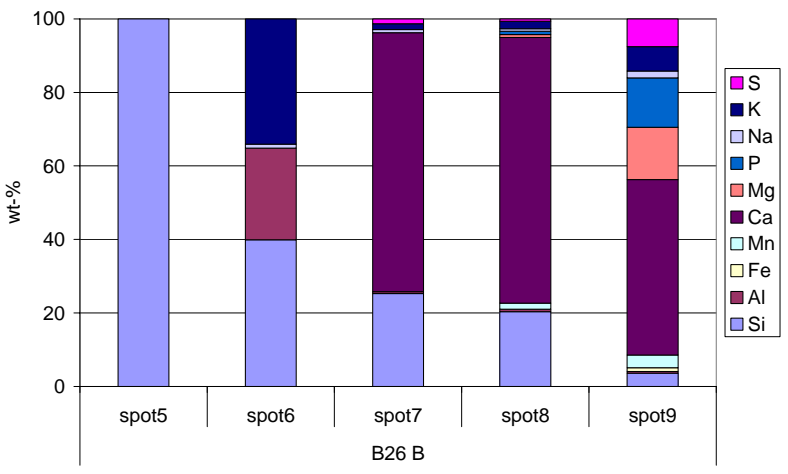

Figure 3 Bed material cross-sections a) RC ash particle - Test WNL45_preliminary, b) bed material particle WNL45_preliminary, c) bed material particle - Test WL18. 
Figure 3a) a rapeseed cake ash particle found in the bottom ash sample during test WNL45_preliminary is shown. Within the ash particle the high concentration of phosphorus next to alkali metals can be noticed (about $35 \mathrm{wt}-\%$ ) indicating that formation of low melting RC ash particles could take place (Lindström et al., 2007). The analyses of bed material cross-sections as shown in Figure $3 \mathrm{~b}$ ) indicate a reaction of potassium compounds with bed material forming low melting alkali silicates (Öhman M. 1999) followed by adhesion of RC ash particles rich in phosphorus. Probably among others potassium phosphates reacted with silica initiating agglomerates formation Barišić V. et al. (2008). The formation of low melting potassium-calcium-silicates during biomass combustion was discussed by Öhman M. (1999) and seems to be valid also in the present co-combustion tests. Addition of limestone changed the combustion behavior by decreasing agglomeration tendency (Figure 3c). The sand particles were coated with a calcium rich layer preventing low melting potassium-silicates formation. This is in agreement with studies done by Barišić et al. (2008) regarding the same experiments.

Table 4 Measurements at the beginning of convective pass.

\begin{tabular}{|c|c|c|c|c|}
\hline \multirow{2}{*}{ Test name } & $\mathbf{R B U}$ & $\mathrm{KCl}+\mathrm{NaCl}$ & $\mathrm{HCl}$ & $\mathrm{SO}_{2}$ \\
\hline & {$\left[\mathrm{g} / \mathrm{m}^{2} * \mathrm{~h}\right]$} & \multicolumn{3}{|c|}{$\left[\mathrm{ppm}_{\mathrm{v}}\right.$ dry flue gas, $\left.6 \% \mathrm{O}_{2}\right]$} \\
\hline "WNL45_preliminary & 16,9 & 114 & 171 & 140 \\
\hline WNL_reference & 1,2 & 1 & 0 & $\overline{0}$ \\
\hline WNL12 & 2,6 & 14 & 44 & 52 \\
\hline WL18 & 6,3 & 49 & 44 & 3 \\
\hline
\end{tabular}

\section{The role of $P$ in deposit formation}

Rates of deposit build-up (RBU) presented in Table 4 indicate that co-firing of wood with $\mathrm{RC}$ showed high fouling rates; rapeseed cake addition from $0-45 \%$ on energy basis caused an increased RBU most probably due to alkali chloride condensation. However, the deposit formation was also aggravated by fine phosphates particles as shown in Figure 4 where the elemental analysis done with the use of SEM/EDX is presented. Figure 4 shows not only an increase of $\mathrm{K}, \mathrm{Na}$ in the deposit samples but also of $\mathrm{P}(9 \mathrm{wt}-\mathrm{\%})$. Increased concentration of $(\mathrm{KCl}+\mathrm{NaCl})$ in the dry flue gas entering the convective pass can be noticed during test WL18 (Table 4). This could be a result of limestone addition which by binding $\mathrm{S}$ didn't allow sulfation of $(\mathrm{KCl}+\mathrm{NaCl})$ (Kassman H. et al., 2006) and as a consequence higher RBU were observed. No influence of limestone addition can be noticed on $\mathrm{HCl}$ entering the convective pass (Table 4) most probably due to measurement uncertainties. Limestone addition seemed to have no impact on the amount of phosphorus (Figure 4) present in the windward side deposits.

\section{CONCLUSIONS}

The fate of phosphorus was investigated during co-combustion tests of rapeseed cake with mixture of wood chips and wood pellets. Chemical fractionation shows that $\mathrm{P}$ in rapeseed cake has different chemical forms: easily soluble $(\mathrm{K}+\mathrm{Na})$ phosphates or organically associated phytic acid salts. Rapeseed cake, rich in $\mathrm{P}$ and $(\mathrm{K}+\mathrm{Na})$, forms ash particles of probably partially molten

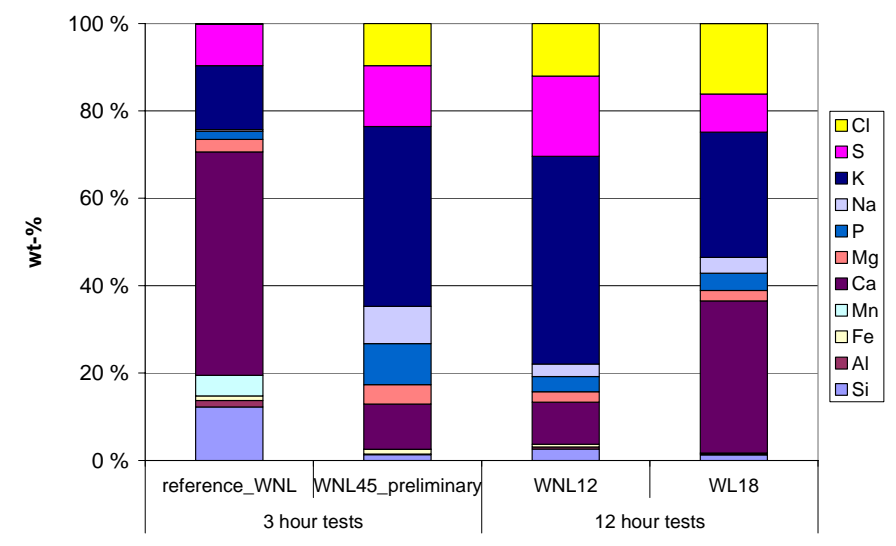

Figure 4 Windward side deposits composition. phases that are aggravating agglomeration, slagging and fouling upon combustion. The elemental distribution over outgoing ash fractions shows that $\mathrm{P}$ is mainly found in the secondary cyclone if not accumulated in the system. Formation of low melting K-silicates followed by adhesion of ash particles, which are rich in $\mathrm{P}$, results in bed agglomeration. Limestone addition causes coating of sand particles preventing low melting silicates formation. Rapeseed cake addition causes an increased rate of deposit build-up (RBU). Windward side of 3-hour exposed ring deposit consists mainly of alkali metal chlorides and sulfates with up to $9 \mathrm{wt}-\%$ of $\mathrm{P}$. Limestone addition does not have significant influence on $\mathrm{P}$ content in the deposit. Combustion of the studied rapeseed cake results in high concentrations of $(\mathrm{KCl}+\mathrm{NaCl})$ but also causes increase in $\mathrm{HCl}(\mathrm{g})$ and $\mathrm{SO}_{2}(\mathrm{~g})$ in the beginning of the convection pass. Co-firing of rapeseed cake with wood turned out to be a problematic case however some $18 \%$ of rapeseed cake on energy basis could be co-fired with wood when limestone is added to the bed. 


\section{Acknowledgements}

This study was carried out as part of the SAFEC project. The financial support of Academy of Finland the Graduate School of Chemical Engineering is gratefully acknowledged. Results of IACM could be used with a permission of Vattenfall $\mathrm{AB}$, which is highly appreciated. Special thankfulness goes to Matti Hiltunen for his key contribution in the early phases of this work. Linus Silvander, Tor Laurén and Piia Leppäsalo are kindly acknowledged for help with the experimental work. Akademiska Hus and the measurement team at the ChUT are kindly acknowledged for their continuous efforts to operate the boiler.

\section{References:}

Barišić V., Åmand L.-E., Coda Zabetta E. "The role of limestone in preventing agglomeration and slagging during CFB combustion of high phosphorus fuels" World Bioenergy, Jönköping (Sweden), May 2008

Baxter L.L. "Pollutant emission and deposit formation during combustion of biomass fuels", Livermore (CA, USA), 1994

Benson S.A., Holm P.L. "Comparison of inorganic constituents in three low-rank coals" Ind. Chem. Eng. Prod. Res. Dev., 24 (1985) 145-149

Cheryan M. "Phytic acid interactions in food systems" Critical reviews in food science and nutrition, 13: 4 (1980)

Coda Zabetta E., Barišić V., Peltola K., Hotta A. "Foster Wheeler Experience with biomass and waste in CFBs" Proceedings of the $33^{\text {rd }}$ Clearwater Conference, Clearwater (Florida, U.S.A.), June 2008

Hupa M. "Ash behavior in fluidized bed combustion-recent research highlights" Proceedings of the $9^{\text {th }}$ International Conference on Circulating Fluidized Beds, Hamburg (Germany), May 2008

Jenkins B.M., Baxter L.L., Miles Jr. T.R., Miles T.R. "Combustion properties of biomass" Fuel processing Technology, 54 (1998) 17-46

Kassman H., Andersson C., Högberg J., Åmand L.-E., Davidsson K., "Gas Phase Alkali Chlorides and Deposits during Co-Combustion of Coal and Biomass", FBC2006-99, Proceedings of $19^{\text {th }}$ International Conference on Fluidized Bed Combustion, Vienna (Austria), May 21-24 2006,

Lindström E., Sandström M., Boström D., Öhman M. "Slagging characteristics during combustion of cereal grains rich in phosphorus" Energy\&Fuels, 21 (2007) 710-717

Nevalainen H., Leino T., Tourunen A., Hiltunen M., Coda Zabetta E. "Deposits and emissions during the co-combustion of biodiesel residue with coal and biomass in a CFB pilot" Proceedings of the $9^{\text {th }}$ International Conference on Circulating Fluidized Beds, Hamburg (Germany), 2008 May 2008

Pontoppidan K., Pettersson D., Sandberg Ann-Sofie "The type of thermal feed treatment influences the inositol phosphate composition" Animal feed Science and Technology 132 (2007)

Shahidi F. "Canola and rapeseed: production, chemistry, nutrition and processing technology", Van Nostrand Reinhold Company Inc. (AVI Book); 1990, ISBN 0-442-00295-5

Skrifvars B.-J., Blomquist J.-P., Hupa M., Backman R. "Predicting the ash behavior during biomass combustion in FBC conditions by combining advanced fuel analysis with thermodynamic multicomponent equilibrium calculations" Proceedings of the 15th Annual International Pittsburgh Coal Conference, Pittsburgh, (PA, USA), 1998

Werkelin J. "Ash forming elements and their chemical forms in woody biomass fuels" PhD thesis, PCC, Åbo Akademi University; 2008, ISBN 978-952-12-2125-5

Zevenhoven-Onderwater M., "Ash-Forming Matter in Biomass Fuels" PhD thesis, Department of Chemical Engineering, Åbo Akademi University; 2001, ISBN 952-12-0813-9

Zevenhoven M., Skrifvars B.-J., Yrjas P., Hupa M., Nuutinen L., Laitinen R. "Searching for improved characterisation of ash forming matter in biomass", Proceedings of the 16th International Conference on Fluidized Bed Combustion, Reno (NV, USA) 2001

Zevenhoven M., Yrjas P., Backman R., Skrifvars B.-J., Hupa M. "The Åbo Akademi database-fuel characterization", FBC2005-78093, Proceedings of the $18^{\text {th }}$ International Conference on Fluidized Bed Combustion, Toronto (Ontario, Canada), May 18-23 2005

Åmand L.-E., Leckner B. "Metal emissions from co-combustion of sewage sludge and coal/wood in fluidized bed" Fuel, 83 (2004) 1803-1821

Öhman M. Experimental studies on bed agglomeration during fluidized bed combustion of biomass fuels. PhD thesis, Department of Chemistry, Umeå University; 1999, ISBN91-7191-646-6 